\title{
Radiological parameters of sagittal plane in children with cerebral palsy, walking or wandering
}

\author{
JC Bernard ${ }^{1 *}$, J Deceuninck', A Combey ${ }^{1}$, E Berthonnaud $^{1,2,3}$ \\ From 9th International Conference on Conservative Management of Spinal Deformities - SOSORT 2012 \\ Annual Meeting \\ Milan, Italy. 10-12 May 2012
}

\section{Background}

The population of cerebral palsy $(\mathrm{CP})$, walking or wandering, often has an abnormal profile clinically, unlike same aged adolescents without neuro-motor dysfunction.

\section{Aim}

So, we wanted, in this work, to realize a radiological assessment of the static data in the spine-pelvis-thigh complex, in children with $\mathrm{CP}$, and made a comparison with an asymptomatic population.

\section{Methods}

The population of CP is made up 119 children, and the asymptomatic population made up of 652 children. The radiographs of the sagittal plane, in large format $(30 \mathrm{~cm} \times 90 \mathrm{~cm})$, are realized in a comfortable position, knees and hips in maximal extension. Analyses were performed, using the Optispine ${ }^{\circledR}$ software, to measure radiological parameters of the whole spine-pelvis-thigh.

\section{Results}

Comparing the two populations, we found no difference in the shape parameter (pelvic incidence) for against a significant difference was demonstrated on the positional parameters (pelvic tilt and sacral slope) of the pelvis. Regarding the spine, we found a difference in the angulation of lumbar lordosis, and the orientation of the latter, as well as the number of vertebrae included in the kyphosis, and its orientation. There is also a significant difference in the $\mathrm{C} 7$ plumb line.

${ }^{1}$ Croix Rouge française CMCR des Massues, Lyon, France

Full list of author information is available at the end of the article

\section{Conclusion}

We can say that the CP population is not specifically different from the control population. Growth disrupts the settings, with the need to prevent these troubles, as soon as possible, to the condition to be concerned, and able to search for.

\section{Author details}

'Croix Rouge française CMCR des Massues, Lyon, France. 'L'Hôpital Nord Ouest, Villefranche sur Saône, France. ${ }^{3}$ Laboratoire de Physiologie de l'Exercice, Université de Lyon, Saint Etienne, France.

Published: 3 June 2013

Reference

1. Berthonnaud E, Labelle H, Roussouly P, Grimard G, Vaz G, Dimnet J: A variability study of computerized sagittal spinopelvic radiologic measurements of trunk balance. J Spinal Disord Tech 2005, 18(1):66-71.

doi:10.1186/1748-7161-8-S1-P17

Cite this article as: Bernard et al:: Radiological parameters of sagittal plane in children with cerebral palsy, walking or wandering. Scoliosis 2013 8(Suppl 1):P17.

Submit your next manuscript to BioMed Central and take full advantage of:

- Convenient online submission

- Thorough peer review

- No space constraints or color figure charges

- Immediate publication on acceptance

- Inclusion in PubMed, CAS, Scopus and Google Scholar

- Research which is freely available for redistribution

Submit your manuscript at www.biomedcentral.com/submit 